\title{
Cytokeratin-14 Staining Method
}

National Cancer Institute

\section{Source}

National Cancer Institute. Cytokeratin-14 Staining Method. NCI Thesaurus. Code C23025.

An immunohistochemical technique to detect cytokeratin14,an intermediate filament protein, using monoclonal antibody to cytokeratin 14 . The technique is used in diagnostic histopathology to identify early squamous metaplasia. 